\title{
CONTEMPORARY AFRICAN PHILOSOPHY: EMERGENT ISSUES AND CHALLENGES
}

\author{
Martin F. Asiegbu* \\ http://dx.doi.org/10.4314/og.v12i 1.1
}

\begin{abstract}
In the opinion of some philosophers, African philosophy, vis-à-vis Western philosophy, African philosophy depicts no more than a particularist exemplar of the universal (Western) philosophy. This paper questions this assumption and demonstrates that, as a human undertaking, all philosophies remain context-dependent and cultureoriented. A contrary view ignores the proper nature of philosophy. A new phenomenon confronts currently confronts all comers to contemporary African philosophy: an expansive vision of African philosophical discourse. Contemporary African philosophers attempt to rethink the initial problems that confronted their pioneer counterparts. Whereas the pioneer African philosophers disputed one another on meta-philosophical issues about African philosophy, their successors, in their bid to give a novel response to those problems, end up introducing innovative frameworks, entirely fresh perspectives, new themes and solutions. As a consequence, they face new challenges. This paper underlines, in broad outline, some of the challenges and urges possible ways to their resolution.
\end{abstract}

Key Words: African identity, hermeneutics and culture, ethnocentric commitment, epistemic impasse.

\section{Introduction}

Contextual constraints, which circumscribe the rise of philosophy in any culture, render philosophy culture-bound. Without prejudice to philosophers who elaborated the ideas of Pure Being, of pure philosophical Truth, and even of Pure Reason, it is the case that humans also possess contextualized Reason, contextualized Truth and this being. Hence, we maintain that the mode of reception of these ideas and our perception of reality must be human. That is to say, this perception (encounter) of reality is always in accordance 
with man's abilities and circumstances. If philosophy is human, it is context-dependent. There is no monolithic philosophy as some European philosophers once assumed, except when it makes use of rationality - applicable to every human being. Given that contexts and interpretations are individual, philosophy, we shall conclude, is bound to contexts therefore. This is the major argument, which validity this paper attempts to demonstrate. Philosophy always arises from a cultural background.

After the long debate on the nature and existence of African philosophy, this philosophy became established, in spite of itself. Contemporary African philosophy has come a long way from its initial beginnings. From its commencement with Tempels's La Philosophie bantoue (1945) to the present state of affairs, the problem of African identity has constantly figured as one of its prominent issues. Really, the problem of African identity, one dares to say, has constituted the basic perennial question of contemporary African philosophy. In various ways, it surfaces in the controversies bedeviling the philosophical discourses. Indeed, it seems to me that there is rather no other factor behind regional philosophies than the issue of identity. Be it Indian, Chinese, French, Finnish philosophies! Even the quest to overcome the hegemony of Western philosophy is, largely, an issue of identity. Indeed, none of the nations of the West need be instructed in that field!

Thus, in spite of the end of the great debate in contemporary African philosophy, the problem of African identity still rears its head in various philosophical discourses. Moreover, the fact that contemporary African philosophers have turned to other concerns in their field, does not lay to rest issues dealing with the identity of the African. One may offer one or two illustrations: Globalization is as much a "buzz" term and phenomenon as it implicates the question of African identity. The problem of green house emissions, the question of ecology, the characterization of gender in Africa vis-àvis the West, e.t.c. - they all deal, in some respects, with the question of the contribution of the African as African! If contemporary African philosophy perceives African identity as a problem tied only to the great debate, then it has lost its basic sense of vision. The question of African identity is equally posed most prominently in 
certain issues dealing with modernity, post-modernity, post-colony, e.t.c. African identity, as a philosophical problem, does not arise merely with the intervention of the West in Africa. Rather, it characterizes that philosophy.

All things considered, we turn to the question of the identity of the African as a point of departure both for contemporary African philosophy and as one of the fundamental concerns of a contemporary African philosopher.

\section{Philosophizing as Africans}

To establish African philosophy, pioneer African philosophers argued against the prevalent negative discourse about Africa. In that guise, they intended achieving intellectually what some African states sought to achieve by warfare (Serequeberhan 1991). Negritude as a philosophy derives its roots from such a counter-discourse about the African. Not only was there the urgency to liberate the African from the clutches of the West, Africans also fought to define that identity, that is to say, to establish themselves as Africans. Both from the quest for freedom and from an attempt to define their identity as Africans did the philosophical task of pioneer African philosophers arise. In contemporary times, the problem of identity continues to determine all philosophizing about Africa. In this regard, the major preoccupation of African philosophers devolves around a single task: searching out answers to, and devising ways of attaining, the purposed goals of African people.

African philosophy, Okere (1983: vii) argues, indexes an attempt of the African to establish his identity. Africans, therefore, seek to establish their identity by their preoccupation with the problems and issues that matter to Africans. These issues include the "present-day African situation as it arises out of the ambiguous and broken heritage of the African past" (Serequeberhan 1991: 13). It implies a study of the crucial problems, which problems are "the lived concerns, the questions and issues embedded in a concrete, existential-historical-political horizon"(13). In short, African philosophy investigates the lived concerns of a culture and of a tradition, as they are disclosed by questions posed from within a 
concrete situation, that serve as the bedrock on which and out of which philosophical reflection is established (13).

Thus, African philosophy is an issue of identity with widespread ramifications. Hence, when African philosophers address the issues of African identity, which identity is, amongst others, one of the problems of immediate concerns to Africans, then they are philosophizing from within their culture. It is limiting, really, to entertain the view of African philosophy as a mere cultural preoccupation; a concern solely with Africa's cultural heritage. More than the issue of culture, there is a further problem - the dilemma of modernity. An African philosopher has hardly any option with problems he has to tackle and address. The typical African situation suggests issues, proposes problems and generates difficulties that serve as objects for philosophizing.

The "African condition," to use Mazrui's phrase, pointedly throws up the problems and daily tasks that preoccupy African philosophers. Simply put, such problems and issues comprehend "the colonised, subjugated, underdeveloped attempt to take hold of his identity" which is, at the same time, "a struggle for more justice and equality" (Okolo 1991: 210). An African philosopher has no choice but to address the question of African predicament (Oguejiofor 2002). Really, "for a particular philosopher, philosophizing necessarily means "to examine in a critical and methodic manner the essential problems of his milieu and of his period" (Towa 1991: 187-200). The problem of identity engendered other issues and debates in African philosophy. Primary among them is the relation of culture to philosophy; whether African philosophy is a feasible venture; whether the sole concern of African philosophy is to expose and study African culture. Debates and other difficulties arise from such and similar views.

\section{Culture as Context of Philosophy: Task of Hermeneutics}

Underlying every culture is what one may refer to as "popular philosophy." This trendy conception of philosophy comprehends witticisms, proverbs, insights about reality, myths and religious conceptions of a distinct people. Such areas of culture, just mentioned, form not only materials for philosophizing, they also 
constitute the background to any philosophy. These resources of a culture are, thus, non-philosophy; they are pre-philosophical (Okere 1976: 4-11). Materials, as these, are found in various cultures: the ancient Greek, the European as well as the African, the American, and even the different Asiatic cultures. In any of these cultures, these provisions, materials and possessions are amenable to philosophical reflection through the work of individual geniuses committed to addressing the problems of a culture. Although their wisdom sayings and their lore of knowledge, enshrined in their traditions and passed on from one generation to the other, do not constitute philosophy, a philosopher is, above all, a lover of wisdom. Where none of the cultural essentials and constituents of a culture make a philosophy, a philosopher, by systematically reflecting on the non-philosophical cultural elements, with a view to imbuing them with meaning, produces a philosophy. So understood, philosophy involves an orderly, organized, critical reflection on a people's entire experience mediated in their culture. The philosopher makes a systematic use of Reason (Okere, 1976: 4-11), as his sole tool, to carry out his work that of attempting to give an ultimate meaning and purpose to reality as a whole.

If philosophy, as Carl Friedrich von Weiszäcker presents it, implies continuous questioning; "asking further" (quoted in Okere, 1983:1) questions, the questioning leaves no presuppositions. Rather, it calls every dimension of culture and all knowledge into question. No part is shielded from the critical questioning of a philosopher, whose purpose is to dub reality with meaning. In this regard, philosophy is "a permanent interrogation of reality through our culture" (1976: 6).

A philosopher's critical reflection is global and total as well. Immersed in a particular culture, a philosopher critically addresses a people's lived experience, their life concerns and their problems in such an ultimate questioning that he produces a reasoned body of text. The text is a discourse "aimed at a transparence $\{$ sic $\}$ as perfect as possible and at the constitution of a conceptual system which tries to coincide with and be adequate to total reality" (6). Philosophy involves a search for the ultimate meaning of reality; it is both this search and a process of reaching at this meaning and purpose of the 
world, of reality as a whole. This strict understanding of philosophy refers to an individual's personal, critical, reflective view as philosophy principally. As such, any type and school of philosophy like the Platonists just as the Idealists - all typify a

...series of individual views $\{-\}$ whose unity consists rather in the type of impulse and intention that animates it, the level of rationality at which it is pitched, the relative homogenuity $\{$ sic $\}$ of the culture inspiring it and dictating its problematique and the aim of global rationality which motivates it (7).

Conceived in this way, philosophy is not culture neither does a popular conception serve as philosophy properly understood. While culture is no philosophy, culture provides the raw material for philosophy. As a result, a philosopher, however intense his love of wisdom, would be devoid of any material for speculation should he do away with culture. In short, without culture, philosophy is impossible. This is the effect of philosophizing within the hermeneutical tradition.

The major reason for such closenessof philosophy to culture is that philosophy is an interpretation, a hermeneutics, a quest for meaning, an attempt at giving meaning to man's world. All attempts at interpretation begin with man himself. As it is, man's attempt at giving meaning entails a self-interpretation. So understood, man's structure and constitution determine his interpretation (philosophy). Any philosophy that results from this auto-interpretation bears the imprint of man's limitations and features. One discovers that man's understanding of his world and his experiences of it are all at once "limited, culture-bound and so historical and situated, and finite" (Okere, 9).

Culture orients a philosopher to a specifically designed group and experience, problems, difficulties and presuppositions of a particular people. African philosophers, as a result, have to take the encounter with the West and the issue of African identity seriously. Since all philosophical discourse involves seeking answers to 
problems and issues, which a culture raises, then a culture is determinative of philosophy. As different and varied as cultures are, so also are the questions, answers and philosophies they generate. Rorty (1993: 43) aptly describes European philosophy as a series of conflicts of ideas that rocked Europe at different epochs. Thus, a European stands a better chance of making sense of the dispute between the Christians and the Marxists, the Newtonians and the Catholics, the Empiricists and the Rationalists, for instance. These disputes involve questions that did not exercise thinkers in other cultures. "The philosophical problematic of Europe," writes Rorty (43), "is a function of particular European quarrels."

Even where different cultures engender similar issues and questions, the philosophies arising from them will definitely vary. The philosophies of the Pre-Socratics, Plato, Aristotle and other Greeks arose as a series of individual critical reflections and interpretation of issues arising out the Greek culture.The questions and issues, which Greek culture generated, questions of the ultimate origin of reality, produced different philosophical discourses from Greek philosophers. The same holds for Christian thinkers like Augustine of Hippo and Thomas Aquinas, who worked in a completely different culture - Christianity. In a similar way, the prevalent culture of World War II made possible the Existentialist philosophies of Jean-Paul Sartre, Jaspers and Heidegger as the modern emphasis on science paved the way for Kant and others. There are no monolithic cultures.

Culture, however significant it is, remains limited to a specific region. European culture is different from African, American, or Asiatic cultures, for instance. Although the geographical particularity of a culture raises the issue of relativism, a creative work in any philosophy, like African philosophy, implies a solid grasp of the (African) culture. It entails a mastery of its lore of knowledge, symbols and symbolism, artefacts, legends and language, laws and customs, poetry and pastimes, celebrations and funerals, religion e.t.c. Only through this way can African philosophers give meaning ultimately to African identity. The reaction of African scholars to European discourse about Africa gave rise to anti-Eurocentrism. 


\section{Anti-Eurocentrism: Africans' Response}

Anti-Eurocentrism forms a large part of Contemporary African philosophy ever since the context of its origin is traceable to the identity struggles of the 1940s/50s. Enormous literatures are accessible in this area because African philosophers easily stray into it. African philosophy, it appears, might lose its bite if it abandons its critically negative stance towards Eurocentrism (Afropessimism), which is why Eze $(1997,1-21)$ depicts it as a "driving factor" of African philosophy. Eurocentrism stands for a "pervasive bias of the European modernity that brutally encountered the African world"(Eze, 1997: 4). It depicts Europe's awareness of its distinctiveness and the consequent denigration of other peoples. "At its core," writes Serequeberhan (1997, 141-161) "is the metaphysical belief or idea that European existence is qualitatively superior to other forms of life." Its emphasis on the dominance of European supremacy, evinced in her technology and advances of science, truncated and false ideologies are unmistaken. For an African to philosophize oblivious of his/her foundations is a disservice to the African world. This view greatly inspires African discourses of Eurocentrism.

Despite several strands of Anti-Eurocentrism, two stand out clearly. The first strand takes a critical stance about Eurocentrism. This strand highlights the subjugation, exploitation and oppression of Africa, conceived as a resultant effect of Eurocentrism in both philosophy and science. In this regard, works of thinkers like LevyBruhl, Darwin, Durkheim and even Evans-Pritchard, and philosophers like Hegel, Kant, Hume, Merleau-Ponty, Simone Weil, Montesquieu, Habermas, and many others are household names. The second strand is deconstructive of Eurocentrism. In this case, one notes that whereas Evans-Pritchard's works, for instance, serves Wiredu's purposes to establish an African alternative to "Western multi-party democracy" (Wiredu 1997: 303-312), these same works are put to another goal by Eze in his critique of Eurocentrism. One notes again that Serequeberhan's powerful interpretation of Kant in his critical discourse of Eurocentrism contrasts with Eze's illuminating discussion of that same Kant (Eze 1997, 103-140). Both 
Serequeberhan and Eze may, after all, not be defending the same view; they may be at cross purposes.

Yet their conflicting interpretations raise unsettling questions about African philosophy and the hermeneutical tool it employs; what the goals of this dimension of African philosophy are; what confusion there is about the nature and proper grasp of African philosophy and what rich interpretations of African culture abound if by African culture, one means to refer to "the common experience of the trauma of the slave trade, of the humiliation that was colonization, of assault on traditional religion, of newly won political independence, of present economic exploitation, of the ambivalent status of standing hesitantly on the threshold of the age of industry" (Okere, 1978:229)

Given the African experience and its history, a critical outlook on Eurocentrism is, indeed, one of the ways of liberating African minds. Yet, the same critique is restrictive of African philosophy. Being no more than a critique, it enforces the prevalence of European philosophical views and categories in African universities. Bernasconi (1997:188) expresses this point thus, "Western philosophy has caught African philosophy in a double outlook." Anti-Eurocentism will remain a significant part of contemporary discourse of African philosophy, if only for the lopsided encounter of European modernity with the African world and the African experience of the same encounter. Where accounts attempt to rewrite centuries of distorted histories, anti-Eurocentrism will command attention, what with the apparent confusion there is about its interpretation and the nature of African philosophy. The impact of this interpretation has generated trends, particularly ethnophilosophy, which negative influence is the ethnocentric commitment.

\section{Insidious Ethnocentric Commitment}

Ever since the hermeneutic turn of Heidegger, Gadamer and Ricoeur, the hermeneutic principle about the context-dependence of all philosophies has come into sharper focus. In the wake of Tempels'sBantu Philosophy (1945/1958), various trends in African philosophy have recognized the tremendous significance of the 
hermeneutic principle. Despite the challenges of the Professional School, ethno-philosophical school of thought remains resilient and irresistibly dominant. Its unconscious influence surfaces in works of African philosophers who do not even acknowledge any commitment to the trend. Though "unintended," "hidden" as its surreptitious influence is, ethnocentric commitment defines an attitude of mind, a "passionate adherence to one's cultural heritage" (Asouzu 2002:38) that obtrudes in one's attempt to define (defend) one's identity, and emphasize one's culture. Above all, it is uncritical about African cultural issues and philosophy. Such a bias takes a critical stance about any issue in Western philosophy while remaining reticent or taking a benign view about any issue in African philosophy.

This commitment chronicles information, myths, symbols and their analysis, without any attempt to relate them to the history of ideas, currents of thought, traditions and philosophical figures. Since these are not unique to Africa, they are merely misrepresentations of African philosophy. Nonetheless, their authors are largely ignorant of the commitment they reserve to ethno-philosophy. If some African philosophers are committed to ethnocentrism, the solutions, which some of them propose to the socio-political and economic problems of African states lack philosophic depth.

\section{Political Theories without Philosophic Depth}

The failure of governance in Africa has focused attention on socio-political philosophy. Literatures in this area have dwarfed works in other branches of philosophy. Thinkers churn out theories in the guise of solutions to the political impasse in Africa. While any form of government could be "bad" or "ideally good," it is not the case that it all depends on the character of those entrusted with membership or of the ruled, nor is failure of governance a purely African lot.

Understood as praxis to regulate the affairs of human being, welfare of individuals and community, governance is a purely human affair. In the bid to resolve the problem of governance in Africa, some political theorists trace it to the corruption of the leaders. These theorists propose checks and balances to this end; 
others emphasize the prevalence of ethnicity and of divided loyalties. For their part, some African philosophers, unlike mere political theorists ought to recognize the need to elaborate a solid metaphysics, a theory of society, anthropology or a theory of human nature, or ethics to ground the political theories. Hobbes's England is a handy illustration.

In the context of Hobbes's England, there prevailed a breakdown of law and order. The significance of Hobbes's Leviathan (1996) for Europe is traceable to his (pessimist) theory of human nature on which his politics is founded. The Leviathan is but a political solution, which ultimately seeks to obviate the basic characteristic of this "poor, brutish" nature of man, as Hobbes expresses it. In contrast, Rousseau's political theory (2010) rejects Hobbes's pessimism to emphasize the fundamentally good and free nature of man. This nature - good in itself - is chained up in the evil influences of civilization and education. For Hobbes and Rousseau, a theory of human nature remains fundamental to their political theories. This is what the emergent political trends in African philosophy are yet to develop. Yet, there is another emerging trend making available a history of African philosophy in several volumes. What challenges do the emergent views and trends in African philosophy present to contemporary African philosophers?

\section{Challenges for African Philosophy}

The challenges to African philosophy are of two major kinds: one deconstructive and the other reconstructive. After a century of Western discourse about the African, definitely, it is the task of the deconstructive challenge to explore and expose the limiting ideas, attitudes, beliefs and ideologies of such an arresting negative discourse that burden the African psyche. Mainly repressive and subjugating of the African, such ideas sub-served equally the postcolonial, socio-economic, political, and cultural institutions in African societies. In no way meant to transform African societies, those institutions vehicle ideologies developed at the expense of African historical heritage. As a result, there arises the need for African philosophers to rethink the principles, concepts, attitudes and ideologies that forged those institutions. Accomplishing such an 
undertaking is, indeed, a major milestone in the arduous task of the deconstructive challenge of African philosophy.

The bid to "decolonize the African mind" (NgugiwaThiong'o, 1996/2009) embodies the reconstructive challenge. As one of the alternative voices and paradigms in philosophy, African philosophy attempts to whittle down the universalism of Western philosophy by opening up other rich possibilities in its purview. If African beliefs and identity were, for some time, mediated through the Western discourse, a reconstructive challenge entails African philosophers creatively originating Africa's discourse in Africa's own categories, systems of thought and models. It requires African philosophers to surpass all foreign conceptual frameworks and their limitations to rewrite, and so alter, the African condition. Mudimbe and Appiah (1993) express this concern for a reconstructive model in the wake of the gradual demise, or better, relativisation of Western philosophy. For them, African philosophy would provide the much needed impetus to guide philosophy should a crisis engulfs Western philosophy. They write,

[A] number of American philosophers - notably Richard Rorty, Stanley Cavell, Cornel West - have become preoccupied with questions about what is distinctively American about American philosophy - or distinctively European about the philosophical culture of Europe. In these circumstances the philosophical climate is ripe for lessons from African work: both because, in exploring the differences between philosophical practices in different places, one is able to approach the question that interests Cavell, Rorty, and West, and because there is a certain openness to new possibilities at the present moment (116).

\section{Chronicle of the History of African Philosophy}

Tomes chronicling the history of African philosophy, its figures, traditions, development, currents of thought, contexts, and periodisation are lacking. All there is, are chapters in books and 
journal articles. This is a promising field of current, discordant, rigorous and laboriously demanding debate in African philosophy. Lacking in African philosophy is a complete and all-encompassing history of African philosophy in the likes of multiple volumes of Western philosophy such as Russell's A History of Western Philosophy (1945/1972). Such a volume will be of immense aid not only to lecturers and students; they can also serve as a great help toward bringing to the fore many issues and difficulties in African philosophy. In some respects, it is a tremendous route to the issue of African identity (Olela 1998: 48-49). Presently, there abound many uncoordinated but sterling individual contributions published, sometimes, in non-philosophical journals. Nonetheless, such a comprehensive history, it seems, is an uphill task, since it entails a forest of problems. We shall mention just three: the status of ethnophilosophy, periodization, and the problem of the Egyptian origin of Greek philosophy. We shall briefly consider each of them, beginning with the status of ethnophilosophy.

\section{(i). The Status of Ethno-philosophy}

Often, thinkers, who focus exclusively on Tempels's work $(1945 / 1958)$ and the reactions, which followed in its wake, erroneously presume that the contemporary period of African philosophy is all there is to this philosophy. While this may be an effect of the great debate about the nature and existence of African philosophy, such thinkers take a lopsided view of this philosophy. Singling out ethno-philosophy as its central theme, some thinkers take African philosophy to begin with the negative Western discourses about Africa and the Africans' counter discourse. Really, to restrict the origins of African philosophy to such discourses excludes the ancient period of African philosophy and confines African philosophy solely to its contemporary era. As Kebede remarks, "African philosophy is not reducible to ethno-philosophy" (Kebede 2004: xi).

The basic issue here has to do with the question, what is the status of ethno-philosophy? Following the original debate about African philosophy, ethno-philosophy is hardly any different from non-philosophy. In this regard, it needn't form a part of the history 
of African philosophy. Or, should it? There is another dimension to ethno-philosophy that perceives it positively as a philosophy. In either case, the most intriguing question about ethno-philosophy involves discovering to which period of the history of African philosophy it belongs: to the ancient period or to the contemporary period. Periodisation is yet another problem.

\section{(ii). Periodization}

How does one classify African philosophy into various periods? Need one toe the path charted already by the West - four periods: ancient, medieval, modern and contemporary? What group of philosophers and schools of thought come under which period? Would such a history classify philosophers like Augustine, Plotinus, Clement of Alexandria and Islamic thinkers as African or European thinkers? In such a history, the different currents, now multiplying in African philosophy, will, definitely, attract attention. The perspective from which one writes such a history will determine its content a great deal.

If thinkers are agreed upon the contemporary period of African philosophy, they are not agreed that ancient Egypt belongs to Africa. In dispute are the Egyptian origin of Greek philosophy and the outstanding civilization of ancient Egypt.

\section{(iii). The Question of the Egyptian Origin of Western Philosophy}

The status of ancient Egypt and its philosophy as the originating source for Greek philosophy is a view that some Africans, like Cheikh Anta Diop (1967/1974) over against Sédar Senghor, defend. Although the dispute of the precedence of Egyptian philosophy over Greek philosophy exercises African thinkers at present, the controversy has been a long-standing issue in history of thought. While such ancient thinkers, like Herodotus, Plato, and Aristotle, for instance, acknowledged their indebtedness to Egypt, some contemporary thinkers limit such an acknowledgement to a minimal influence.

Some accomplished European thinkers and historians of philosophy reject the thesis of Greek philosophy borrowing from either Indian or African philosophy. These philosophies provide no 
evidence of an independent pursuit of knowledge for its own sake a distinctive trait of Greek thought, the "uncontested original thinkers and scientists of Europe" (Copleston 1962/1985: 16). Copleston follows the opinion of Burnet (1802) to dismiss the thesis of the Egyptian origin of Greek philosophy.

For Burnet and some others, it is out of question to argue about the African origin of Greek philosophy. The decisive point, Burnet argues, is, first of all, to establish that the supposed originators of Greek thought possessed a philosophy. As for the Egyptian origin of Greek thought, he writes, "that the Egyptians had a philosophy to communicate has never been shown, and it is out of the question to suppose that Greek philosophy came from India or from China" (15). Some Egyptologists and some African philosophers follow Burnet and Copleston's opinions. They consider the claim of Egyptian origin of Greek philosophy merely as an attempt to associate Africa with the progress of some ancient past that has hardly anything doing with the rest of Africa. To consider Egyptian philosophy as a precedent to the Greeks' is to take an undue advantage of the historical importance of ancient Egypt and its civilization, they argue (Okafor 1997: 251-267).

\section{A New Perception of the Great Debate}

In the context of "the ideology of European dominance" (Richards 1979: 3-18) and the politics of knowledge, it would have been all too naïve, indeed preposterous, had African philosophers presumed that the great debate about the nature and existence of African philosophy purposed to deal merely with the nature of African philosophy and the "conditions of its possibility" (Okere 1983). Ultimately, the debate isolated the alterity of the African. Decades after the great debate, some African philosophers have been assessing the debate and the issues that fueled the controversy. If some of these philosophers applaud the fundamental issue of the discourse as the search for the identity of the African (Masolo 1996: 251) and even more provocatively as "Europe Upside Down" (Appiah, 1997: 728-731; Oguejiofor, 2003: 477-498), others - with hindsight - decry the long and unduly dissipated effort the debate gulped. 
For this latter group, contemporary African philosophy set out on a wrong footing, since it made meta-philosophical issues of "what is philosophical and non-philosophical" (Oladipo 2000: 29) the focus of the debate. In the end, the perspectives to the debate came to reveal the bone of the contention as the quest to model African philosophy after its Western counterpart. Ethnophilosophers became inclined to domesticating Western philosophy in the guise of creating an authentic philosophy out of the traditional African past. Despite its pretensions to reject the Western model of philosophy and to privilege the traditional African past, ethnophilosophy ended up embracing African otherness. In this way, it endorsed Lévy-Bruhl'sprelogism and its attendant colonial discourse. The presumed 'authentic African philosophy' proved to be no more than an uncritical reception of multiple components of African culture - worldviews, cultural symbols, artifacts, religion, language, etc. Taken together, these elements constitute 'philosophy' in that vulgar sense of the term that ethno-philosophers propose. For under such a loose articulation of philosophy, everything imaginable falls. Really, only from such a perspective does Tempels constitute an African model for Senghor and Anyanwu, while Lévy-Bruhl, of all thinkers, made, in Momoh's view, a major original contribution to African philosophy (Oladipo 1998: 26)!

To obviate the pitfalls of ethno-philosophy, the Professional current rejects the otherness of the African as the colonial discourse represented it. Nonetheless, the Professional school failed to chart a way for a plurality of non-Western philosophies. Its inability to achieve this feat forces it to embrace the West's conception of philosophy as a guiding model. This failure presents African philosophy in a bad light. It makes it a mere appendage of the West. In no other way does the Professional approach manifest this outlook than in its requirement that the possibility of philosophy is dependent on the existence of science, a view that makes philosophy an inquiry into science. For it presumes that there is a core essence to all philosophies. To privilege the idea of an essence of philosophy emphasizes the West as the eternal model for other philosophies and disciplines. 


\section{Great Debate and New Problems}

Bogged down with trifles, the various trends lost the orientation of the great debate. One finds Wiredu (1980:14-15) upbraiding African philosophers for "talking about African philosophy as distinct from doing it." The prolonged period spent on the debate (Ogumodede 2000: 26. 28. 30) is yet another pointer to its misguided orientation. In addition, Oladipo (2000: 26, 28, 30) contends that the debate did principally ignore "real" African problems: African condition and its modernization. African philosophers, Oladipo maintains, failed "to philosophize with the contemporary [African] situation in mind" (26). Concisely stated, they did not grapple with "the issue of what should be the nature of the philosopher's contribution to selfknowledge in Africa", and "the struggle and destiny of the African people" (28). As a result, they lost sight of addressing the question of the relevance of African philosophy (28). In their attempt to replicate the Western idea of philosophy in Africa, they denied African philosophy the freedom and dynamism to develop positively in an unfettered, conducive African environment (30).

\section{Formation of Students in Philosophy}

The mistaken direction of the debate generated a crisis in African philosophy. The nature of the crisis is best illustrated in the training that African universities have charted for students of philosophy. Abiding by the individual countries' regulations and UNESCO's directives for the study of philosophy, African universities emphasized, principally, the study of Western philosophy, introducing courses in African philosophy much later, perhaps, as an afterthought. Some African Universities, moreover, attach no importance to African philosophy. The adverse impact, which such reprehensible attitudes bear on the formation of African students, stand out in the students' inability to contribute meaningfully to their societies.

In this regard, Unah (2008: 37-47) argues that adequate training in philosophy requires painstaking formation in the core philosophical disciplines of the quadrivium. He insists that these courses afford the students essential tools for addressing the problems of their societies. Unah's major argument goes against 
some African scholars, who insist on grooming students in applied philosophy from the onset. If African philosophy is considered as 'applied philosophy,' then Unah's view suggests a transportation of Western model into Africa. Unah writes.

For the African to earn respect in universal patrimony of philosophy, it [his/her formation] must be rigorous, it [his/her formation] must be profound and it [his/her formation] must proceed from the core disciplines native to philosophy (40).

If Unah means that, to be reckoned with, African philosophy must take its model from the West, then he founds intellectual formation in Africa on the ideology of the West. But this is different from Unah's view.

Without core disciplines (quadrivium), students' training in philosophy becomes truncated. This is Unah's view. Such students, Unah maintains, would lack a sure foundation. Students of philosophy are wont to ask about the practical results of philosophy. One of the most commonly posed questions is this, "of what use is metaphysics, abstract as it is, to a gainful employment afterwards?" This question is similar to the one that Unah's paper deals with, why the formation in the core disciplines of philosophy? Oladipo (2000: 109-110) states the response in a simple language: to "inculcate in us [students] certain intellectual skills we [students] need [in order] to contribute to self-knowledge in our own [African] societies." In this way, Oladipo continues, African universities can "produce the kind of graduates [that] Africa needs, namely, people who can identify some human problems and apply their minds to them, without being bogged by academic stereotypes or received opinions."

\section{Research Grants and Sponsorships}

The crisis is 'writ large' in the area of research. Given the biting pains of poverty and the apparent disinterestedness of African leadership in fostering research, African scholars turn to the West for research grants and sponsorships. Since 'he who pays the piper dictates the tune,' some African philosophers conduct their 
researches on those themes and areas that are not quite beneficial to Africa (!) Put another way, the African experience rarely remains significant to the researches of some African philosophers, since they lose interest in the socio-economic, the historico-political conditions of Africa and become estranged from their environment. Rather than philosophize from within their culture and environment in which they are embedded, they prefer the Western milieu to these. The consequence of this estrangement is enormous. Africa, in the third millennium, still grapples with the teething problems that confronted her at the period of independence: debt problem, hunger, poverty, lack of basic amenities, absence of adequate technology and scientific advance, energy resources, corruption and poor governance, e.t.c. Instead of taking a giant stride towards modernization, Africa resembles a goat tethered to a tree, which does not go beyond the circumference its cord permits.

To modernize adequately from her traditional past, African philosophers need not restrict their activities only to the "description, reconstruction, and at times mystification of traditional African world-views, concepts and ideas" (Oladipo 2000: 97-98). To them falls the task of reappraising African culture in a way that encourages development, modernization and a deconstruction of mental outlook of the African, exposing, at the same time, the illadvised ideologies mushrooming in Africa at present.

\section{Conclusion}

Given the historical origins of African philosophy, a past in which Europe is portrayed in a bad light, some European universities and thinkers may not all too readily warm up to African philosophy. Anti-Eurocentric discourses are intriguing if African thinkers focus greater attention on ethnophilosophical trend. Yet, it remains a big question, why African philosophy is kept alive through a propagation of Western philosophy? Yet, there abounds an avalanche of possibilities and resources for African philosophy. As a potentially fertile ground, it behooves African philosophers to integrate anti-Eurocentric critiques in their bid to creatively generate African philosophy out of these emergent themes mentioned above. 
In this way, they will obviate the dominance and resilience of ethno-philosophical trend and its insidious influence that most thinkers are unaware of and tend to defend as African philosophy. The tendency to collapse ethnocentrism into anti-Eurocentrism is as unpromising as are some political theories elaborated to address the African political condition, theories without in-depth philosophical basis. Just as the elaboration of political theories with grounded philosophical depth is indispensable to the solution of Africa's socio-political problems, so also does the chronicling of the thoughts, figures, influences, texts, environments of African philosophy as a text of a history of this philosophy remain one of the greatest challenges to all African philosophers.

*Martin F. Asiegbu, Department of Philosophy, University of Nigeria, Nsukka.Martin.asiegbu@unn.edu.ng 
Asiegbu: Contemporary African Philosophy...

\section{References}

Burnet, J. (1802) Early Greek Philosophy.London: Adam and Charles Black.

Diop, A. C. Civilization Or Barbarism. An Authentic Anthropology. Tr. Y-L. M. Ngemi, New York: Lawrence Hill Books.

Eze, E. C. (1997) 'Introduction: philosophy and the (Post) colonial, in Postcolonial African Philosophy: A Critical Reader,' in E. C Eze.(ed), Postcolonial African Philosophy: A Critical Reader, p. 1-21. Cambridge, Massachusetts: Blackwell.

Eze, E. C. (1997) 'The idea of 'Race' in Kant's Anthropology', in E. C. Eze (ed), Post-Colonial African Philosophy. A Critical Reader, pp. 103-140.Massachusetts: Blackwell Publishers.

Gadamer, H-G.(1975) Truth and Method. J. Weinsheimer and D. G. Marshall (eds), London: Sheed and Ward.

Hountondji, P. (1983) African Philosophy: Myth or Reality. Bloomington: Indiana University Press.

Hountondji, P. (1995) African Philosophy: Selected Readings. A. G. Mosley (ed), Englewoods, N. J.: Prentice-Hall

Rousseau, J. J. (2010) On the Social Contract. New York: Classic Books International.

Kagame, A. (1956) La philosophiebantoue-rwandaise de l'être. Brussels: Académie Royale des Sciences Coloniales.

Kagame, A. (1976) La philosophiebantouecomparée. Paris: PrésenceAfricaine.

Karp, I. \&Masolo, D. A. (2000), African Philosophy as Cultural Inquiry. Bloomington: Indiana University Press.

Kebede, M. (2004) Africa's Quest for a Philosophy of Decolonization. New York: Radopi. 
Ogirisi: a new journal of African studies vol 122016

Lévy-Bruhl, L. (1985) How Natives Think. translated by L.A. Claire, New Jersey: Princeton University Press.

Masolo, D. A. (1994) African Philosophy in Search of Identity. Bloomington: Indiana University Press.

Mudimbe, V. Y. (1988) The Invention of Africa: Gnosis, Philosophy, and the Order of Knowledge. London: James Currey.

Mudimbe, V. Y. and K. A. Appiah. (1993) 'The Impact of African Studies on Philosophy,' in R. H. Bates \& V. Y. Mudimbe (eds), Africa and the Disciplines: The Contributions of Research in Africa to the Social Sciences and Humanities. 113-138. Chicago: University of Chicago Press.

Oguejiofor, J. O. (2001) Philosophy and African Predicament. Ibadan: Hope Publications.

Oguejiofor, J. O. (2003) 'Probelms and Prospects of a History of African Philosophy', American Catholic Philosophical Quarterly 77(4):477 - 498.

Oguejiofor, J. O. (2009) 'Negritude as Hermeneutics: A Reinterpretation of Léopold Senghor's Philosophy,' American Catholic Philosophical Quarterly 83(1): 79-94.

Ogumodede F., (2000) African Philosophy Down the Ages: 10,000BC to the Present. Ibadan: Hope Publications.

Okafor, F. (1997) 'A Survey of African Philosophy in Comparison with Western Philosophy' Journal of Value Inquiry 30(1): 1017.

Okere, T. I. (1976) 'The Relation Between Culture and Philosophy', Uche 2:4-11.

Okere, T. I. (1983) African Philosophy: A Historico-Hermeneutical Investigations of the Conditions of Its Possibility. Lanham: University Press of America. 
Asiegbu: Contemporary African Philosophy...

Okere, T. I. (ed), (1996) Identity and Change. Nigerian Philosophical Studies.Washington D. C.: Paideia.

Okolo, C. B. (1993) African Social and Political philosophy: Selected Essays. Nsukka: Fulladu.

Okolo, O. (1997) 'Tradition and Destiny: Horizons of an African Philosophical Hermeneutics', in T. Serequeberhan (ed), African Philosophy: The Essential Reading, p. 3-18. New York: Paragon House.

Oladipo, O. (2000) The Idea of African Philosophy. A Critical Study of the Major Orientations in Contemporary African Philosophy. Ibadan: Hope Publications.

Olela.H.. (1998) 'African Foundations of Greek Thought,' in E. C. Eze (ed), African Philosophy: AnAnthology, p. 43-49. Malden: Blackwell.

Richards, D. (1979) 'The Ideology of European Dominance', PrésenceAfricaine 111:3-18.

Rorty, R. (1993) 'Stories of Difference: A Conversation with Richard Rorty', Bulletin: (V) 2-3:23-45.

Russell, B. (1945/1972) A History of Western Philosophy.New York: Touchstone Book.

Serequeberhan, T. (1994) The Hermeneutics of African Philosophy: Horizon and Discourse. New York: Routledge.

Serequeberhan, T. 1991) 'African Philosophy: The Point in Question', in T. Serequeberhan (ed), African

Philosophy: The Essential Reading, p.3-28. New York: Paragon House.

Serequeberhan, T. (1997) 'The Critique of Eurocentrism and the Practice of African Philosophy,'in E. C. Eze (ed), PostColonial African Philosophy: A Critical Reader, 141-161. Massachusetts: Blackwell Publishers.

Snowdown, F. (1983) Before Race Prejudice: The Ancient View of Blacks. Massachusetts: Harvard University Press. 
Tempels,P.(1945/1958) Bantu Philosophy. Paris: PrésenceAfricaine

Towa, M. (1991) 'Conditions for the Affirmation of a Modern African Philosophical Thought', in T. Serequeberhan (ed), African Philosophy: The Essential Reading, 187-200. New York: Paragon House.

Unah, J. (2008) 'Doing Philosophy and Doing African Philosophy', in M. F. Asiegbu\& J. C. Agbakoba (eds), Four Decades of African Philosophy: Issues and Perspectives, p. 37-47. Ibadan: Hope Publications.

WaThiong'o, N. (1996) Decolonizing the Mind: The Politics of Language in Africa. London: Heinemann.

Wiredu, K. (1980) African Culture and Philosophy. London: Cambridge University Press.

Wiredu, K. (1997) 'Democracy and Consensus in African Tradition', in C. M. Eze (ed), Post-Colonial African Philosophy: A Critical Reader, p. 303-312. Massachusetts: Blackwell Publishers. 